\title{
Transstadial Transmission of Pythium in Bradysia impatiens and Lack of Adult Vectoring Capacity
}

\author{
Sarah E. Braun, Louela A. Castrillo, John P. Sanderson, Margery L. Daughtrey, and Stephen P. Wraight
}

First, second, and third authors: Department of Entomology, and fourth author: Department of Plant Pathology and Plant-Microbe Biology, Cornell University, Ithaca, NY 14853-0901; and fifth author: United States Department of Agriculture-Agricultural Research Service Robert W. Holley Center for Agriculture \& Health, Ithaca, NY 14853-2901.

Accepted for publication 5 August 2010.

\begin{abstract}
Braun, S. E., Castrillo, L. A., Sanderson, J. P., Daughtrey, M. L., and Wraight, S. P. 2010. Transstadial transmission of Pythium in Bradysia impatiens and lack of adult vectoring capacity. Phytopathology 100:13071314.

Fungus gnats have been shown to transmit a variety of plantpathogenic fungi that produce aerial dispersal stages. However, few studies have examined potential interactions between fungus gnats and oomycetes, including Pythium spp. A series of laboratory experiments were conducted to determine whether fungus gnat adults are vectors of several common greenhouse Pythium spp., including Pythium aphanidermatum, $P$. irregulare, and $P$. ultimum. An additional objective was to

determine whether $P$. aphanidermatum can be maintained transstadially in the gut of a fungus gnat larva through the pupal stadium to be transmitted by the subsequent adult. Adult fungus gnats did not pick up infectious Pythium propagules from diseased plants and transmit them to healthy plants in any experiment. Species-specific primers and a probe for real-time polymerase chain reaction were developed to detect the presence of $P$. aphanidermatum DNA in fungus gnat tissue samples. $P$. aphanidermatum DNA was detectable in the larval and pupal stages; however, none was detected in adult fungus gnats. These results are in agreement with previous studies that have suggested that adult fungus gnats are unlikely vectors of Pythium spp.
\end{abstract}

Fungus gnats of the genus Bradysia (Diptera: Sciaridae) are ubiquitous pests in greenhouse crop-production systems (12). The larval stages of these insects inhabit the soil, where they feed primarily on decaying plant materials and associated fungi (17, 27); however, in the absence of preferred foods, they will attack live, healthy plants. Damage is often limited and inconsequential and sometimes potentially beneficial (1) but large (late-instar) larvae may sever the primary roots or bore into the soft stems of young seedlings or cuttings, with lethal effects. The short-lived adults of these insects do not cause any direct plant damage; they are generally described as either aphagous or as feeding on nectar or other liquids $(17,27)$. Steffan (27) described them as feeding "primarily on organic ooze." Because of their association with decaying vegetation, fungus gnats are commonly found to coexist with diseased plants, and their role as vectors of plant pathogens has been under investigation for many years. Studies have revealed that adult fungus gnats can acquire and mechanically transport the aerial spores of various plant pathogens. This has been most commonly demonstrated for fungal conidia, including those of Fusarium, Thielaviopsis, and Verticillium spp. (57,10,11,16).

Although there is ample evidence that fungus gnats can vector aerial-spore-producing pathogens, a significant role in the transmission of pathogens that do not generate large numbers of such readily transmissible propagules has not been demonstrated. A large number of important pathogens of this type comprise the genus Pythium in the class Oomycetes (29). These fungus-like microbes (commonly called water molds) do not produce winddisseminated propagules; dispersal is via active movement of

Corresponding author: S. E. Braun; E-mail address: sea35@ cornell.edu

doi:10.1094/PHYTO-04-10-0117

(c) 2010 The American Phytopathological Society zoospores or passive transport in water, soil, or plant materials. As soilborne pathogens, Pythium spp. are responsible for root and crown rots of mature plants and damping-off of seedlings. Persistence in the soil is by saprophytic growth and (primarily) by production of thick-walled sexual spores (oospores) in or on the infected tissues of their host plants. Their activity as root rot pathogens accounts for their frequent association with fungus gnats.

Studies over the past two decades have revealed that oospores of Pythium spp. are readily ingested by fungus gnat larvae, survive passage through the gastrointestinal tract, and, after being ejected in the frass, can germinate and infect plants under laboratory conditions $(9,14,15)$. Larval fungus gnats, however, are soft-bodied, scotophilic inhabitants of soil and other substrates. Thus, their mobility is limited, and they are not likely to account for significant transmission of Pythium spp. between greenhouse facilities, between benches within a greenhouse, or even between separated pots on a greenhouse bench. Pythium spp. and other water molds are fully capable of persisting in soil as oospores and dispersing short distances through soil as zoospores or actively growing mycelia without reliance on insect vectors. Acquisition and transport of Pythium propagules by adult fungus gnats would be of much greater significance, yet this has been investigated in only a few studies. Favrin et al. (8) were unable to isolate Pythium spp. from adult fungus gnats collected near diseased plants in British Columbia greenhouses. Jarvis et al. (15) reported from direct microscopic observations that Pythium aphanidermatum (Edson) Fitzp. oospores ingested by Bradysia impatiens (Johannsen) larvae persisted in the body and were identifiable in the digestive tracts of the pupal and adult stages. However, relatively few oospores were observed in pupae and very few in the adults, and the oospores from neither of these life stages were found viable. Furthermore, adult fungus gnats did not ingest $P$. aphanidermatum oospores suspended in sugar water or externally transmit $P$. aphanidermatum $\mathrm{CFU}$ from petri dishes with active 
cultures to dishes with a sterile agar substrate. These findings led Jarvis et al. (15) to conclude that "adults probably play only a minor role" in dissemination of $P$. aphanidermatum.

Despite this evidence of low potential for long-distance dissemination of Pythium spp. by fungus gnats, the perception persists that these insects are important vectors of these pathogens $(14,23)$. The primary objective of the current study was to further evaluate the Pythium spp.-vectoring potential of adult fungus gnats by assessing the capacity of $B$. impatiens adults to acquire infectious propagules of $P$. aphanidermatum, $P$. ultimum Trow, or $P$. irregulare Buisman from diseased plants and transmit them to healthy plants (geranium seedlings) under laboratory conditions highly favorable for infection. An additional objective was to develop and apply a molecular probe (real-time polymerase chain reaction [PCR]) to detect and quantify transstadial transmission of $P$. aphanidermatum in B. impatiens.

\section{MATERIALS AND METHODS}

Insect rearing. A laboratory colony of $B$. impatiens was established with adults collected from a greenhouse on the Cornell University campus. Adults and larvae were routinely reared in plastic containers $(9.8 \mathrm{~cm}$ in diameter by $6.2 \mathrm{~cm}$ in depth) (Pioneer Plastics, Dixon, KY) with lids bearing holes $(5.5 \mathrm{~cm}$ in diameter) covered with nylon mesh $(95 \mu \mathrm{m})$ for ventilation. Fifty fungus gnat adults (predominately females) were placed into each container for oviposition and provided with $\approx 40 \mathrm{~g}$ of growing medium (Premier Pro-Mix BX, Quakertown, PA) mixed with $\approx 10 \mathrm{~g}$ (dry weight) of ground pinto beans (Phaseolus vulgaris L.) and saturated with tap water. Colony containers were maintained at $27 \pm 1^{\circ} \mathrm{C}$ with $14 \mathrm{~h}$ of light and $10 \mathrm{~h}$ of darkness (14:10 L:D) for immature development and subsequent adult emergence.
To obtain an even-aged cohort of fourth-instar fungus gnat larvae for use in bioassays, $\approx 200$ adult fungus gnats were collected from colony containers and released into a 45-by-45-by$45.5-\mathrm{cm}$ cage in the laboratory at ambient temperature $\left(\approx 24^{\circ} \mathrm{C}\right)$ and allowed to oviposit on 90-by-15-mm petri dishes (Becton Dickinson Labware, Franklin Lakes, NJ) that contained saturated cotton covered with a piece of black filter paper spread with a thin layer $(\approx 1.6 \mathrm{~g})$ of ground pinto beans. After $24 \mathrm{~h}$, petri dishes were removed from cages and the fungus gnat cultures maintained at $27 \pm 1{ }^{\circ} \mathrm{C}$ until the larvae completed development to the fourth instar. Additional water and pinto beans were added to the dishes as needed to provide adequate food and water. Fourth-instar larvae were readily identified on the surface of the filter paper and transferred to bioassay containers using a fine brush.

Plant propagation. Geranium seed (Pelargonium $\times$ hortorum L. H. Bailey 'Orbit White'; Goldsmith Seeds) were surface sterilized in a $0.5 \%$ sodium hypochlorite solution and germinated individually in tight-lid petri dishes ( 47 by $10 \mathrm{~mm}$ ) lined with one disk of filter paper (42.5 $\mathrm{mm}$ in diameter) saturated with $400 \mu \mathrm{l}$ of sterile distilled water $\left(\mathrm{SDH}_{2} \mathrm{O}\right)$. The seeds were incubated in darkness for 3 days at room temperature. The seedlings were then maintained at $27 \pm 1{ }^{\circ} \mathrm{C}$ and 14:10 L:D and watered daily (with $200 \mu \mathrm{l}$ of $\mathrm{SDH}_{2} \mathrm{O}$ ) until used in bioassays. The seedlings were oriented, for the most part, horizontally in the petri dishes (lying on the filter paper).

At the initiation of bioassays, seedlings were 8 days old (days post seed hydration), $\approx 5$ to $6 \mathrm{~cm}$ in length, and consisted of a short stem terminating in two cotyledons and an unbranched root with dense root hairs.

Pathogen maintenance and oospore production. All microbes used in the study are listed in Table 1 . Three species of Pythium commonly affecting greenhouse crops (13) were selected

TABLE 1. List of microbes used in this study

\begin{tabular}{|c|c|c|c|}
\hline Species, strain & Host, substrate & Year & Origin \\
\hline \multicolumn{4}{|l|}{ Pythium aphanidermatum } \\
\hline $\mathrm{B}-2$ & Euphorbia pulcherrima & 2008 & Pennsylvania \\
\hline GDF2 & E. pulcherrima & 2007 & Connecticut \\
\hline GSM-1 & Pelargonium & 2006 & Pennsylvania \\
\hline H6-1 & Chrysanthemum & 2008 & New York \\
\hline Holl-2 & E. pulcherrima & 2007 & New York \\
\hline Jo-5 & Chrysanthemum & 2007 & New York \\
\hline $\mathrm{K}-13$ & Chrysanthemum & 2007 & New York \\
\hline $\mathrm{K}-17$ & Chrysanthemum & 2008 & New York \\
\hline Lab-14 & Chrysanthemum & 2007 & New York \\
\hline Lab-18 & Chrysanthemum & 2008 & New York \\
\hline P-52 & Soil & 2001 & New York \\
\hline $\mathrm{Pa}-58$ & Gypsophila paniculata & 1999 & Israel \\
\hline Par-2 & Chrysanthemum & 2005 & New York \\
\hline P. acanthicum VB-37 & Soil & 2001 & New York \\
\hline P. angustatum TG-16 & Soil & 2000 & New York \\
\hline P. carolinianum $\mathrm{NH}-66$ & E. pulcherrima & 2000 & New Hampshire \\
\hline P. dissotocum $\mathrm{Bb}-08-48$ & Soil & 2008 & New York \\
\hline P. elongatum $\mathrm{T}-1$ & Mix on fabric or floor & 2000 & New York \\
\hline P. graminicola L-59 & Soil & 2001 & New York \\
\hline \multicolumn{4}{|l|}{ P. irregulare } \\
\hline Par-1 & Pelargonium & 2005 & New York \\
\hline $13-7$ & Pelargonium & 1997 & Michigan \\
\hline $13-10$ & Pelargonium & 1997 & Michigan \\
\hline $13-29$ & Pelargonium & 1997 & Florida \\
\hline $13-30$ & Pelargonium & 1997 & Florida \\
\hline $13-57$ & Pelargonium & 1997 & Florida \\
\hline $13-59$ & Pelargonium & 1997 & Florida \\
\hline P. oligandrum DT-1 & Cupressus $\times$ leylandii & 2007 & New York \\
\hline P. plurisporium $\mathrm{Wb}-3$ & Water or irrigation system & 2007 & New York \\
\hline P. splendens $\mathrm{NF}-3$ & Acer & 2007 & New York \\
\hline P. sylvaticum BB-08-43 & Soil & 2008 & New York \\
\hline P. torulosum Pt-1 & Impatiens & 2001 & New York \\
\hline P. ultimum $\mathrm{P} 4$ & Phaseolus vulgaris & 1978 & New York \\
\hline P. vexans $\mathrm{T}-38$ & Floor dirt & 2000 & New York \\
\hline Thielaviopsis basicola & Calibrachoa & 2007 & New York \\
\hline
\end{tabular}


for study. P. aphanidermatum strains Pa-58 and K-13, P. ultimum strain $\mathrm{P} 4$, and $P$. irregulare strain Par 1 were grown on V8 juice agar in 60-by-15-mm petri plates maintained in the dark at $27 \pm$ $1^{\circ} \mathrm{C}$ (recipe for 24 plates comprised $100 \mathrm{ml}$ of V8 juice, $400 \mathrm{ml}$ of $\mathrm{H}_{2} \mathrm{O}, 1.5 \mathrm{~g}$ of $\mathrm{CaCO}_{3}$, and $10 \mathrm{~g}$ of Bacto Agar). One-week-old cultures of the various Pythium spp. were used in all experiments. Every 2 weeks, the pathogens were reisolated from 11-day-old geranium seedlings that had been inoculated 3 days earlier by placing a 6-mm-diameter agar disk (from 1-week-old culture) of Pythium on the root tip. Each infected seedling was placed in a 90-by-15-mm petri dish and covered with molten water agar $(2 \%)$ supplemented with $1 \mathrm{ml}$ of rifampicin, $1 \mathrm{ml}$ of penicillin $\mathrm{G}$, and $2.5 \mathrm{ml}$ of kanamycin per liter of $\mathrm{SDH}_{2} \mathrm{O}$ (WARP). Pythium hyphae that grew rapidly through the agar were excised from the surface of the medium and transferred to a fresh WARP plate. Additional strains and species of Pythium obtained for testing real-time PCR assay specificity were maintained on half-strength corn meal agar (CMA) plates (Difco Laboratories, Detroit, MI) incubated in the dark at $25 \pm 1{ }^{\circ} \mathrm{C}(8.5 \mathrm{~g}$ of CMA per liter of $\mathrm{SDH}_{2} \mathrm{O}$ ).

Thielaviopsis basicola (Berk. \& Broome) Ferraris cultures were grown on potato dextrose agar (MP Biomedicals, Solon, $\mathrm{OH}$ ) in 60 -mm-diameter petri dishes and maintained in the dark at $24 \pm$ $1^{\circ} \mathrm{C}$. One-week-old cultures of $T$. basicola were used in all experiments. Every 2 weeks, the pathogen was reisolated from 18-day-old geranium seedlings that had been inoculated 10 days earlier as described above for the Pythium spp.

Oospores of $P$. aphanidermatum were produced in 90-by-15$\mathrm{mm}$ petri dishes in a defined liquid medium composed of $3 \mathrm{mg}$ of $\mathrm{K}_{2} \mathrm{HPO}_{4}, 1.6 \mathrm{mg}$ of $\mathrm{KH}_{2} \mathrm{PO}_{4}, 0.17 \mathrm{mg}$ of thiamine, $5 \mathrm{mg}$ of $\left(\mathrm{NH}_{4}\right)_{2} \mathrm{SO}_{4}, 1.1 \mathrm{mg}$ of $\mathrm{CaCl}_{2}, 1.3 \mathrm{mg}$ of asparagine, $0.18 \mathrm{~g}$ of dglucose, and $1 \mathrm{~g}$ of lecithin per liter of $\mathrm{SDH}_{2} \mathrm{O}$ (25) and maintained in the dark at $27 \pm 1^{\circ} \mathrm{C}$ for 12 days. Medium was dispensed in 20-ml aliquots into the petri dishes, and each dish was inoculated with a 6-mm-diameter agar disk (from 1-week-old culture) of $P$. aphanidermatum grown on V8 agar. Oospores were isolated from culture dishes by using a sterile scalpel to cut mycelium away from the agar inoculum disk. The resulting mat of $P$. aphanidermatum mycelium was placed in a sterile $50-\mathrm{ml}$ centrifuge tube with $5 \mathrm{ml}$ of $\mathrm{SDH}_{2} \mathrm{O}$ and $\approx 1.15 \mathrm{~g}$ of sterile $2-\mathrm{mm}$ diameter glass beads. Tubes were shaken for $10 \mathrm{~min}$ on a wristaction shaker set at 6.7 oscillations/s (Model BT; Burrell Scientific, Pittsburgh, PA) and each Pythium suspension was poured through a sterile $53-\mu \mathrm{m}$ sieve into a sterile $50-\mathrm{ml}$ centrifuge tube. Samples were stored at $-20^{\circ} \mathrm{C}$ until use.

Acquisition and retention of $P$. aphanidermatum by adult fungus gnats. In total, 100 assay replicates were conducted to determine whether adult fungus gnats are capable of acquiring and retaining $P$. aphanidermatum from culture dishes. Two 2-dayold female fungus gnats (from pupae surface sterilized in a $0.5 \%$ sodium hypochlorite solution) were used in each assay. Prior to the initiation of an assay, the vials containing fungus gnats were chilled in a refrigerator $\left(4^{\circ} \mathrm{C}\right)$ for $10 \mathrm{~min}$ to temporarily immobilize them during treatment.

Two treatments were included in each assay. In the first, one fungus gnat was grasped by the wings with fine forceps and dragged around the circumference of a $P$. aphanidermatum culture on V8 agar. The inoculated fungus gnat was then transferred to a 60-mm-diameter petri dish and submerged in molten WARP that had been cooled to $45^{\circ} \mathrm{C}$. In the second treatment, a similarly dragged and inoculated fungus gnat was transferred to a dish containing solidified WARP. The plates were examined after 24 and $48 \mathrm{~h}$ for hyphal growth. If growth was evident after 2 days, the microbes were reisolated and grown on V8 agar to morphologically confirm the presence of $P$. aphanidermatum.

Transmission study with plants in plastic dishes. In total, 11 assays with $P$. aphanidermatum and 12 assays each with $P$. ultimum and $P$. irregulare were conducted to assess the capacity of adult fungus gnats to acquire and transmit Pythium spp. to healthy geranium seedlings. Twelve assays were conducted using T. basicola as a positive control because adult fungus gnats have previously been shown to transmit this pathogen (5). Batches of 8 -day-old geranium seedlings were grown on filter paper and half of the seedlings in each batch were inoculated with agar plugs from $P$. aphanidermatum, $P$. ultimum, $P$. irregulare, or $T$. basicola cultures as previously described. All seedlings were maintained at $27 \pm 1{ }^{\circ} \mathrm{C}$ and 14:10 L:D and watered daily (with $200 \mu \mathrm{l}$ of $\mathrm{SDH}_{2} \mathrm{O}$ ) until used in bioassays. Seedlings used in Pythium sp. bioassays were 11 days old and those used in T. basicola bioassays were 15 days old at the start of the assay; by this time, all inoculated seedlings were patently infected or dead and exhibited external growth of Pythium hyphae or Thielaviopsis conidiation. Ten 2-day-old fungus gnats (five males and five females) were used in each assay. Assays were conducted in plastic containers $(9.8 \mathrm{~cm}$ in diameter by $6.2 \mathrm{~cm}$ in depth) with tight-fitting, unventilated lids. The bottom of each container was lined with a piece of filter paper $(90 \mathrm{~mm}$ in diameter) saturated with $1.5 \mathrm{ml}$ of $\mathrm{SDH}_{2} \mathrm{O}$. Four small (35 $\mathrm{mm}$ in diameter) petri dishes, each containing $5 \mathrm{ml}$ of water agar covered with a 25 -mm-diameter piece of filter paper saturated with $100 \mu \mathrm{l}$ of $\mathrm{SDH}_{2} \mathrm{O}$, were placed in the bottom of each assay container.

Three treatments were included in each assay. For the first treatment, two healthy (noninoculated) seedlings were placed diagonally across from one another in the small petri dishes, and two infected seedlings were placed in the remaining two dishes (Fig. 1). Ten fungus gnats (five female and five male) were then released in the assay container. The second treatment was the same as the first except no fungus gnats were added. For the third treatment, four noninoculated plants plus 10 fungus gnats ( 5 female and 5 male) were added to the assay container. In all treatments, noninoculated plants were examined for disease symptoms after incubation for 7 days under the above-described environmental conditions. Adult fungus gnats are short lived; they survived and were active in the containers for $\approx 2$ days.

In the case of $P$. ultimum, assays were conducted in larger plastic containers $(15.0 \mathrm{~cm}$ in diameter by $2.5 \mathrm{~cm}$ in depth) (BD Falcon, Franklin Lakes, NJ) lined with a 125 -mm-diameter piece of filter paper saturated with $2 \mathrm{ml}$ of $\mathrm{SDH}_{2} \mathrm{O}$; matching containers were used as lids. After 2 days in the presence of fungus gnats, each pair of noninoculated plants on the small petri dishes from the three treatments was transferred to a clean 9.8 -by- $6.2-\mathrm{cm}$ assay chamber. It was necessary at this time to separate the noninoculated plants from the diseased plants because preliminary assays had revealed that hyphae of $P$. ultimum were capable of rapid growth from dish to dish (across the moist filter paper lining the bottom of the chamber).

Transmission study with seedlings on plug mix. In total, 12 assays were conducted to further assess the capacity of adult fungus gnats to acquire and transmit $P$. aphanidermatum to healthy geranium seedlings. Infected seedlings were obtained as previously described. In this experiment, infected or noninfected seedlings were laid directly on the surface of the potting medium in expectation that provision of an attractive oviposition site might enhance the contact between the fungus gnats and the seedlings. Assays were conducted in the 9.8-cm-diameter containers filled with $\approx 40 \mathrm{~g}$ of Redi-Earth Plug and Seedling Mix (Sun Gro Distribution Inc., Bellevue, WA) saturated with $\mathrm{SDH}_{2} \mathrm{O}$.

Two treatments were included in each assay. In all, 35 11-dayold geranium seedlings showing root rot characteristic of $P$. aphanidermatum infection were placed on top of the plug mix in one container, and 35 11-day-old noninoculated geranium seedlings were placed on top of the plug mix in a second container (seedlings were distributed as evenly as possible) (Fig. 1). Fifty 2-day-old female fungus gnats were then released into each container. After 24 h, 20 fungus gnats from each treatment were 
collected with forceps and transferred to new assay containers, with 35 healthy seedlings also on plug mix, as described. These plants were examined for disease symptoms after 7 days. An additional 10 fungus gnats from each treatment were removed
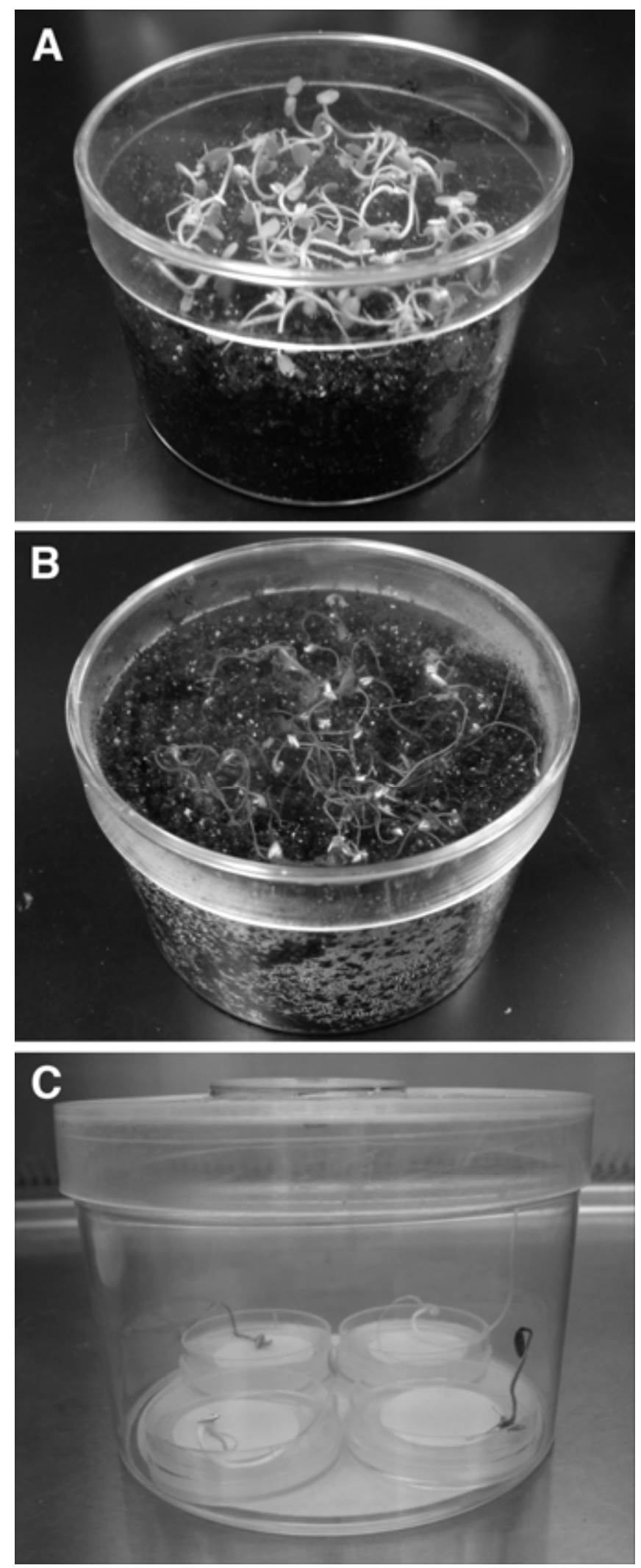

Fig. 1. A, Noninoculated geranium seedlings in transmission study with seedlings on plug mix. B, Geranium seedlings infected with Pythium aphanidermatum in transmission study with seedlings on plug mix. C, Set-up for transmission study with plants in plastic dishes. from the original assay containers, placed in 60-mm-diamater petri dishes, and covered with molten WARP. The plates were examined after 24 and $48 \mathrm{~h}$ for $P$. aphanidermatum growth.

Transstadial transmission. The intent of this experiment was to determine whether $P$. aphanidermatum oospores ingested during the ultimate larval instar persist in the fungus gnat body through pupation and adult eclosion. Using a fine brush, groups of 25 early-fourth-instar larvae were transferred from rearing dishes to each of 21 petri dishes containing $2 \%$ water agar. Larvae were maintained in the dark at $27 \pm 1{ }^{\circ} \mathrm{C}$ and allowed to feed on the water agar for $6 \mathrm{~h}$ to clear their guts. They were then transferred onto sterile filter paper saturated with $\mathrm{SDH}_{2} \mathrm{O}$ and allowed to move on this substrate for $10 \mathrm{~min}$ to dislodge surface contaminants. At this point, 3 or 4 larvae were selected from each of three randomly sampled plates and placed into sterile $1.5-\mathrm{ml}$ microcentrifuge tubes ( 1 larva/tube, total of 10 larvae). All specimens were then frozen at $\approx-20^{\circ} \mathrm{C}$ until analyzed. Each group of larvae from each of the remaining 18 dishes was transferred to a V8 agar plate containing a $P$. aphanidermatum culture from which the aerial mycelium had been removed using a sterile scalpel. This plate feeding method was used because fungus gnats could not be induced to feed on purified preparations of oospores produced in the defined liquid medium. After $15 \mathrm{~h}$, a sample of three or four larvae was taken from each of three randomly selected plates and placed on sterile filter paper saturated with $\mathrm{SDH}_{2} \mathrm{O}$ to remove surface contaminants. Each larva was then put into a sterile $1.5-\mathrm{ml}$ microcentrifuge tube and frozen. This sampling was repeated from an additional three randomly selected plates at $48 \mathrm{~h}$ from the start of the experiment. Pupae were similarly sampled from all culture plates within $24 \mathrm{~h}$ after pupation. Additional pupae were transferred to dishes lined with moist filter paper for adult emergence; adults were collected within $1 \mathrm{~h}$ of eclosion and immediately frozen.

The entire experiment was conducted three times with $P$. aphanidermatum strain Pa-58, providing grand totals of 26 to 33 insects of each age group. Most adult fungus gnats (28 of 33) were collected from the third experimental replicate after modifications were made to the handling protocol (pupae removed too quickly from their pupation sites in the culture plates suffered high rates of mortality). To account for any possible strain variation in transstadial transmission, the above-described experiment was also conducted once with $P$. aphanidermatum strain $\mathrm{K}-$ 13, providing totals of 15 pupae and 25 adults for molecular analysis. Eight meconial deposits were examined microscopically $(\times 400)$ for the presence of oospores immediately after adult emergence in plastic dishes.

DNA extraction from oomycetes and fungus gnats. For DNA extraction from Pythium spp. for PCR assays, a 0.5 -cm agar plug from the growing edge of each strain was inoculated into $8 \mathrm{ml}$ of potato dextrose broth in a 60-by-15-mm petri dish and incubated in the dark at $25^{\circ} \mathrm{C}$ for 4 to 7 days. Mycelium $(\approx 100 \mathrm{mg}$, wet weight) was collected in a 2 -ml bead beating tube (Sarstedt, Newton, NC), washed with sterile distilled water, and spun for $10 \mathrm{~min}$ at $14,000 \mathrm{rpm}$, and the pellet used immediately for DNA extraction. Zirconia/silica beads $(0.5 \mathrm{~g})$ and $400 \mu \mathrm{l}$ of AP1 lysing buffer with $4 \mu$ of RNase (Qiagen DNeasy Plant Mini Kit; Qiagen, Valencia, CA) were added to each tube and the samples were homogenized for $30 \mathrm{~s}$ at 4,200 rpm in a Mini Bead Beater (BioSpec Products, Bartlesville, OK). Subsequent DNA extraction steps proceeded as recommended by the manufacturer (Qiagen). DNA was eluted in $100 \mu \mathrm{l}$ of Tris ( $\mathrm{pH}$ 8.0), quantified using a spectrophotometer (Eppendorf, Westbury, NY), and stored at $-20^{\circ} \mathrm{C}$ until use.

To equate DNA quantity with oospore numbers, oospores of $P$. aphanidermatum strain Pa-58 were suspended in sterile distilled water at a stock concentration of $1.68 \times 10^{5}$ per $100 \mu$ quantified via hemacytometer counts. Expected concentrations of $8.4 \times 10^{4}$, $1.68 \times 10^{4}, 8.4 \times 10^{3}, 1.68 \times 10^{3}, 840$, and 168 oospores per 
$100 \mu \mathrm{l}$ were subsequently prepared from a series of alternating five- and twofold dilutions of the stock suspension. A 100- $\mu$ l sample of each oospore suspension was then spun for $10 \mathrm{~min}$ at $14,000 \mathrm{rpm}$ and the pellet resuspended in $400 \mu \mathrm{l}$ of AP1 lysing buffer. Samples were ultimately processed using the same DNA extraction protocol described for mycelia.

For DNA extraction from fungus gnats, individual specimens (larvae, pupae, and adults) were surface sterilized by immersion in $70 \%$ ethanol, washed twice with sterile distilled water, dried on autoclaved filter paper, and transferred to $1.5-\mathrm{ml}$ sterile microcentrifuge tubes. Each specimen was triturated in $50 \mu \mathrm{l}$ of AP1 lysing buffer (Qiagen) using a sterile 1.5-ml Kontes pellet pestle (Kimble Chase, Vineland, NJ). Another $350 \mu \mathrm{l}$ of lysing buffer was added and DNA extraction proceeded as reported above. The grinding step was added to break up the insect sample and release its gut content. DNA was eluted in $50 \mu \mathrm{l}$ of Tris $\mathrm{pH} 8.0$ and stored at $-20^{\circ} \mathrm{C}$ until use.

PCR primers and TaqMan probe. Real-time PCR primers and probe were designed using Beacon Designer software (version 6.1; Premier Biosoft International, Palo Alto, CA), based on $P$. aphanidermatum ITS complete sequence and partial sequence of the 5.8S rRNA gene (accession AF310331). This sequence was amplified with $P$. aphanidermatum-specific primers Pa1 and ITS2 (30). We also tested the specificity of this primer pair by running standard PCR assays against several more $P$. aphanidermatum and other Pythium spp. strains using conditions reported by Wang et al. (30). Several real-time PCR primer pairs were developed and again tested for specificity against a set of $P$. aphanidermatum and Pythium spp. strains by standard PCR. PCR reaction mixtures $(25 \mu \mathrm{l})$ contained $1 \times$ PCR buffer with $1.5 \mathrm{mM}$ $\mathrm{MgCl}_{2} ; 200 \mu \mathrm{M}$ each dATP, dCTP, dGTP, and dTTP; $0.5 \mu \mathrm{M}$ each primer; $1.0 \mathrm{U}$ of Taq polymerase (Qiagen); and $20 \mathrm{ng}$ of template DNA. PCR amplification was performed in a PTC-200 thermal cycler (MJ Research, Waltham, MA) programmed for initial denaturation at $94^{\circ} \mathrm{C}$ for $4 \mathrm{~min} ; 30$ cycles of $94^{\circ} \mathrm{C}$ for $1 \mathrm{~min}$ and 56 to $66^{\circ} \mathrm{C}$ or $62^{\circ} \mathrm{C}$ for $1 \mathrm{~min}$; and extension at $72^{\circ} \mathrm{C}$ for $1 \mathrm{~min}$. PCR products were visualized on $1 \%$ agarose gels stained with ethidium bromide. Assays were repeated at least twice for each strain. Additional specificity assays were conducted using realtime PCR against a subset of the strains and species initially tested. The selected primers were Pa4F (5'-GAACCGTTGAAA TCATGTTCTGTG) and Pa1R (5'-TACATCGGCAGACTAC AATTAAGC), which amplified a 81-bp product. This primer pair was specific to $P$. aphanidermatum and also showed the lowest calculated threshold $(\mathrm{Ct})$ values. The $\mathrm{Ct}$ value is the cycle at which a given sample reaches a point of fluorescent intensity above background, which can be correlated to the starting concentration of target DNA. The probe PaTq (5'-CCCACCTTCGT TCAGCCCTCCCG) was labeled at the $5^{\prime}$ end with fluorescent FAM reporter dye and at the $3^{\prime}$ end with TAMRA quencher dye (Integrated DNA Technologies, Coralville, IA).
Real-time PCR. Real-time PCR assays were conducted using the iCycler iQ5 real-time PCR detection system (Bio-Rad Laboratories, Foster, CA). Each reaction mixture (25- $\mu$ l final volume) contained $1 \times$ iQ Supermix (Bio-Rad Laboratories), $0.5 \mu \mathrm{M}$ each primer, $0.125 \mu \mathrm{M}$ probe, and $2 \mu \mathrm{l}$ of each of the standard or sample DNA. Thermal cycling conditions were as follows: $95^{\circ} \mathrm{C}$ for $10 \mathrm{~min}$, followed by 40 cycles of denaturation at $95^{\circ} \mathrm{C}$ for $15 \mathrm{~s}$, and a single-step annealing and extension at $60^{\circ} \mathrm{C}$ for $1 \mathrm{~min}$. Each PCR assay included a standard curve of 6 to 7 series 10 -fold dilution from $40 \mathrm{ng}$ to $0.4 \mathrm{pg}$ or $10 \mathrm{ng}$ to $0.001 \mathrm{pg}$ of Pa-58 DNA (or K-13 DNA for assays with that strain) for determining the starting concentrations of unknowns and a nontemplate control. Assays were performed on duplicate samples, and at least two independent assays were performed for each experiment.

Statistical analyses. Statistical tests were conducted using the JMP software, version 7.0 (26). A linear regression analysis (with intercept constrained to zero) was conducted of $P$. aphanidermatum DNA detected versus oospore number. Analysis of variance (ANOVA) followed by the Tukey-Kramer test for means comparisons were used to examine differences in amounts of $P$. aphanidermatum DNA in insect samples. The $\log (X+1)$ transformation was applied prior to ANOVA to normalize the distributions and equalize the treatment variances.

\section{RESULTS}

Acquisition and retention of $\boldsymbol{P}$. aphanidermatum by adult fungus gnats. In the case of the $45^{\circ} \mathrm{C}$ water-agar treatment, $P$. aphanidermatum colonies grew on $11 \%$ of the plates. $P$. aphanidermatum colonies grew on only $1 \%$ of the plates in the solidified water-agar treatment.

Transmission study with plants in plastic dishes. For all three treatments with the pathogens $P$. aphanidermatum, $P$. ultimum, and $P$. irregulare, the seedlings remained healthy and free of disease symptoms after 7 days. With $T$. basicola, the positive control, 10 of the 12 noninoculated (healthy) seedlings became infected in the dishes containing 2 diseased seedlings, 2 healthy seedlings, and 10 fungus gnats. Only 1 of 12 healthy seedlings became infected with $T$. basicola in the dishes without fungus gnats. No healthy seedlings became infected in the untreated controls (Table 2).

Transmission study with seedlings on plug mix. In both treatments (35 infected geranium plants with 50 fungus gnats or 35 noninoculated plants with 50 fungus gnats), plants remained healthy and free of disease symptoms after 7 days (Table 2). Also, no $P$. aphanidermatum growth was observed on the water-agar plates onto which fungus gnats that had been exposed to diseased plants were released.

Correlation of $P$. aphanidermatum DNA with oospore number. The relationship between estimated amounts of DNA and

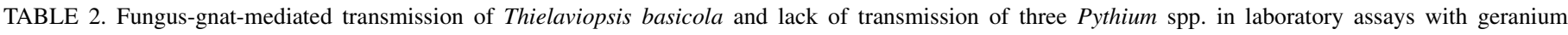
seedlings

\begin{tabular}{|c|c|c|c|c|}
\hline \multirow[b]{2}{*}{ Treatment } & \multicolumn{4}{|c|}{ Percent transmission ${ }^{\mathrm{x}}$} \\
\hline & T. basicola & Pythium aphanidermatum & P. ultimum & P. irregulare \\
\hline \multicolumn{5}{|l|}{ Seedlings on filter paper ${ }^{y}$} \\
\hline $\mathrm{DS}+\mathrm{HS}$ with FG & $83(10 / 12)$ & $0(0 / 11)$ & $0(0 / 12)$ & $0(0 / 12)$ \\
\hline DS + HS without FG & $8(1 / 12)$ & $0(0 / 11)$ & $0(0 / 12)$ & $0(0 / 12)$ \\
\hline Control (HS with FG) & $0(0 / 12)$ & $0(0 / 11)$ & $0(0 / 12)$ & $0(0 / 12)$ \\
\hline \multicolumn{5}{|l|}{ Seedlings on peat-based plug mix $^{z}$} \\
\hline FG from DS transferred to HS & - & $0(0 / 12)$ & - & - \\
\hline Control (FG from HS transferred to HS) & - & $0(0 / 12)$ & - & - \\
\hline
\end{tabular}


numbers of oospores was described by the equation $0.0004 \times$ number of oospores (Fig. 2). However, because larvae ingested a mix of mycelia and oospores in this study, we were not able to use this relationship to determine numbers of oospores ingested (Discussion).

Transstadial transmission. For strain Pa-58, no evidence of $P$. aphanidermatum was detected in larvae that fed on water agar ( $n=30$ ). However, larvae placed on $P$. aphanidermatum cultures overnight $(n=30)$ contained an average of $24.52 \pm 8.68 \mathrm{pg}$ of $P$. aphanidermatum per insect, with $100 \%$ of the samples containing some level of $P$. aphanidermatum (Table 3). Larvae placed on $P$. aphanidermatum cultures for $48 \mathrm{~h}$ had less $P$. aphanidermatum per insect, with $80 \%$ of the samples containing some level of $P$. aphanidermatum. Insects retained the pathogen until pupation, with $92 \%$ of the samples containing some level of $P$. aphanidermatum. No $P$. aphanidermatum was detected in adults $(n=33)$, suggesting that they did not retain any $P$. aphanidermatum from larval feeding (Table 3 ).

Similar results were observed with $P$. aphanidermatum strain $\mathrm{K}-13$. Oospores were readily observed in larvae that fed on $P$. aphanidermatum K-13 culture plates (Fig. 3), and 93\% of the pupal samples contained some level of $P$. aphanidermatum. The molecular probe detected no $P$. aphanidermatum in the adults $(n=$ 25) (Table 3), and we observed no microscopic particles resembling Pythium oospores in the excreted meconia.

\section{DISCUSSION}

Pythium spp. are responsible for a broad range of root rot, crown rot, and cutting diseases in floricultural crop production (21). Primary sources of Pythium spp. in the greenhouse include diseased plants (especially plants with subclinical infections), contaminated potting media, irrigation water, and soil adhering to

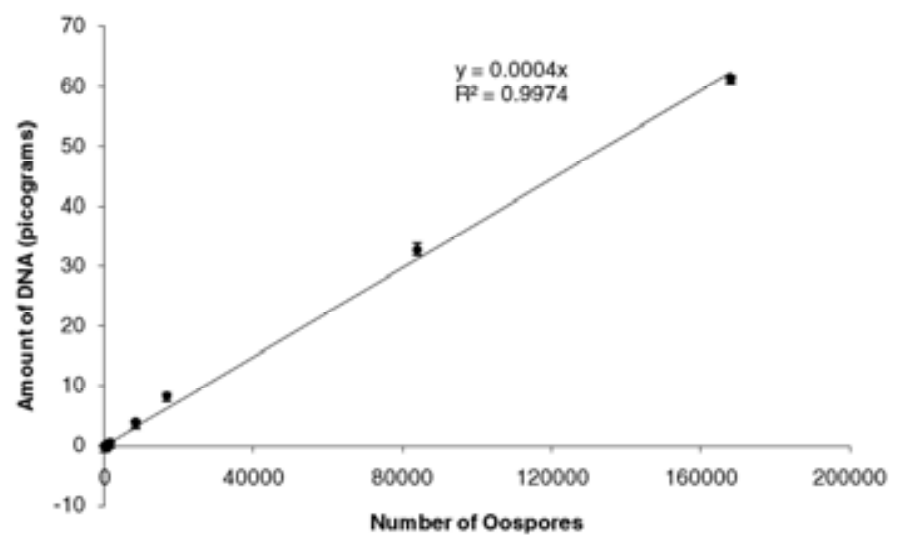

Fig. 2. Relationship between number of Pythium aphanidermatum strain $\mathrm{Pa}-58$ oospores and amount of DNA in picograms.

TABLE 3. Mean picograms of Pythium aphanidermatum in insect samples detected by real-time polymerase chain reaction

\begin{tabular}{lcc}
\hline Treatment & $\begin{array}{c}\text { No. of } \\
\text { specimens }\end{array}$ & $\begin{array}{c}\text { P. aphanidermatum/ } \\
\text { specimen }(\mathrm{pg})(\mathrm{range})^{\mathrm{z}}\end{array}$ \\
\hline Strain Pa-58 & 30 & 0 \\
$\quad$ Larvae fed agar & 30 & $24.52 \pm 8.68 \mathrm{a}(0.02-215)$ \\
Larvae fed Pythium for $15 \mathrm{~h}$ & 30 & $3.01 \pm 1.09 \mathrm{~b}(0-22.62)$ \\
Larvae fed Pythium for $48 \mathrm{~h}$ & 26 & $5.24 \pm 1.33 \mathrm{~b}(0-22.25)$ \\
Pupae & 33 & 0 \\
Adults & & \\
Strain K-13 & 15 & $6.01 \pm 1.31(0-10.14)$ \\
Pupae & 25 & 0 \\
Adults &
\end{tabular}

${ }^{\mathrm{z}}$ Mean picograms of $P$. aphanidermatum/insect specimen (range of values). Means followed by the same letter are not significantly different (TukeyKramer test; $\alpha=0.05)$. cultivation equipment and grower's clothing. In addition, growers and scientists have long suspected that fungus gnats could be another significant source of inoculum in disease outbreaks. However, the results from our investigations, in conjunction with the observations of Favrin et al. (8) and the findings of Jarvis et al. (15), strongly indicate that this is not the case - that fungus gnats, in fact, have a very low Pythium spp.-vectoring potential.

Only $11 \%$ of the fungus gnats that were dragged through $P$. aphanidermatum cultures produced Pythium colonies when immersed in molten agar and just $1 \%$ when placed on solidified agar. This suggests that most of the acquired inoculum consisted of fragmented hyphae that were either never viable or rapidly lost viability. CFU likely consisted of large masses of hyphae (possibly including oogonia and oospores) deposited on the legs or bodies of the insects by the force of the artificial manipulation.
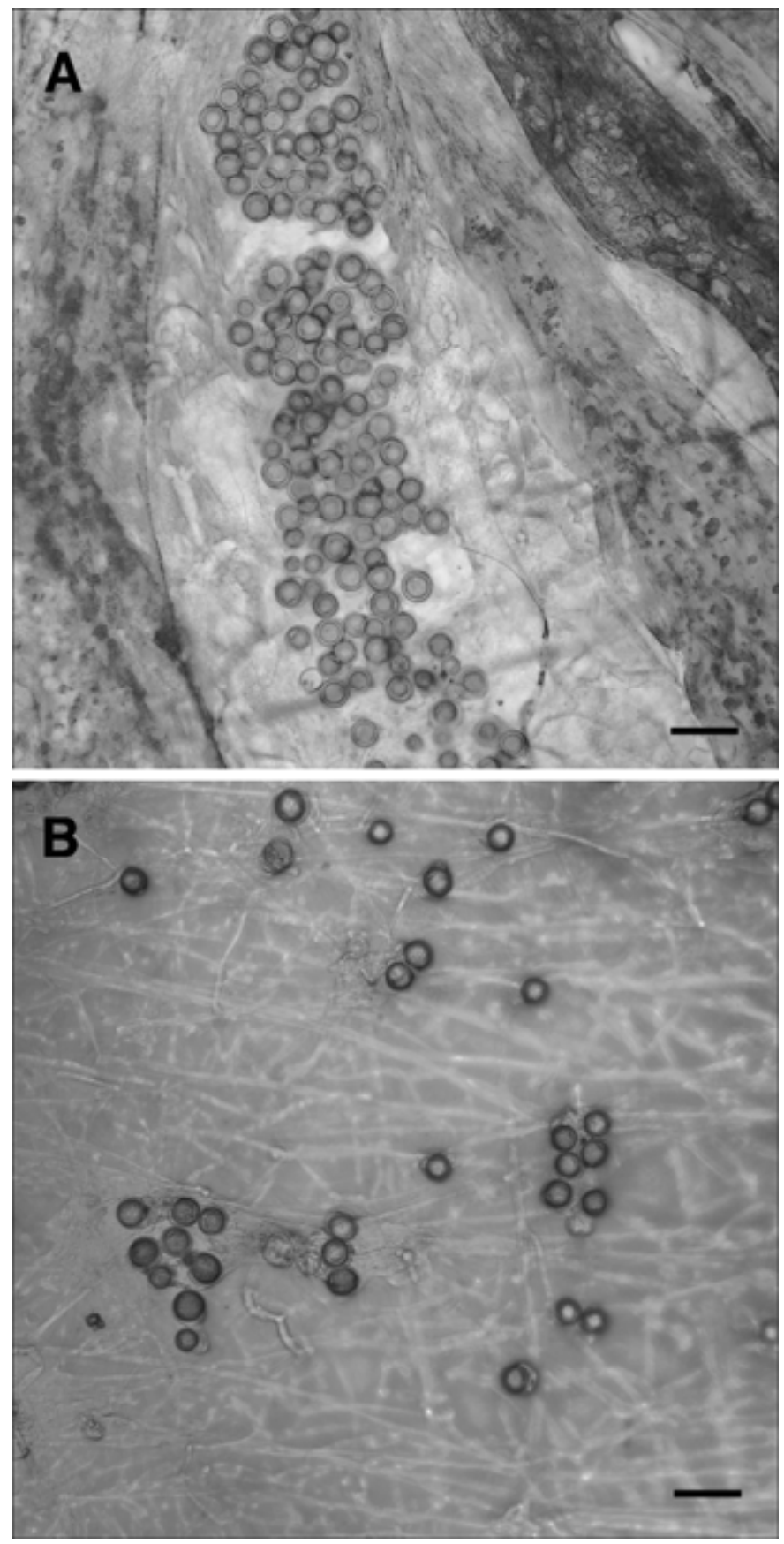

Fig. 3. A, Oospores of Pythium aphanidermatum strain K-13 in the digestive tract of a fungus gnat larva. B, Surface of $P$. aphanidermatum strain K-13 culture plate where fungus gnat larvae were placed to feed. Scale bars $=50 \mu \mathrm{m}$. 
In contrast, adult fungus gnats permitted to move freely (naturally) on the diseased seedlings or Pythium spp.-contaminated plug mix did not pick up and transmit an infectious dose or CFU of inoculum in any of our tests. In our cultures of $P$. aphanidermatum, $P$. ultimum, and $P$. irregulare, few oospores and no sporangia were observed on aerial hyphae that would have been subject to collection by the fungus gnats. Oospore production was confined primarily to the agar matrix.

In their natural habitats, the sexual and asexual reproductive structures of Pythium spp. are produced primarily belowground, inaccessible to adult fungus gnats. The mycelia of these microbes are made up of fine, coenocytic filaments that are extremely vulnerable to desiccation (20) and represent an equally unlikely source of inoculum for fungus gnat transmission. Many species of Pythium, including $P$. irregulare and $P$. ultimum (but not $P$. aphanidermatum), produce thin-walled asexual spores commonly referred to as hyphal swellings $(18,28)$. Though potentially becoming airborne via soil dust or rain splash, these spores are not specifically adapted for wind dissemination like the caducous, desiccation-tolerant conidia of many fungi and, thus, are also unlikely to be picked up by insect vectors. Of the fungal plant pathogens known to be transmitted externally by adult fungus gnats, all produce abundant conidia aboveground on infected host tissue. In the case of $T$. basicola, used as a positive control in this study, these conidia were readily acquired and disseminated by adult fungus gnats.

We were unable to detect $P$. aphanidermatum DNA in adult fungus gnats using real-time PCR. This would appear to contradict the observations of Jarvis et al. (15), who reported finding $P$. aphanidermatum oospores in $1.7 \%$ of adult fungus gnats fed Pythium during the larval stage. Actual numbers of oospores observed in these adults were exceedingly low, however ( $\leq 2 /$ adult), and such low numbers are likely below the detection threshold of our PCR assay. The smallest amount of DNA detected in our tests was $0.002 \mathrm{pg}$ which, according to the estimate of $0.0004 \mathrm{pg} / \mathrm{oospore}$, would represent approximately five oospores. Positive visual identification of individual microbial spores in insect tissues is exceedingly difficult (it was this difficulty, in fact, that prompted us to develop a molecular probe), and we did not attempt examination of pupal or adult digestive tracts.

The large amounts of $P$. aphanidermatum DNA found in the actively feeding larvae in our experiments (mean: $25 \mathrm{pg} / \mathrm{larva}$ ) translates to $>60,000$ oospore equivalents. Ingestion of agar with oospores at the densities produced by the $P$. aphanidermatum isolates used in this study could not have produced such numbers (Fig. 3B), and we did not observe high concentrations of oospores in any larvae. To account for this discrepancy, it must be concluded that most of the detected DNA came from ingested hyphae. This could explain the precipitous drop in the amount of DNA found in larvae allowed to feed for $48 \mathrm{~h}$ (Table 3). Many of these larvae were nearing pupation by that time and had ceased feeding. During the prepupal or so-called wandering period, digestion continues (4), and much of the DNA, especially that ejected from ruptured hyphae, was probably subjected to rapid degradation. Even so, large amounts of DNA ( $>10,000$ oospore equivalents) persisted into the pupal stage. It may be that a portion of the hyphal DNA was protected in some way, perhaps encapsulated in agar or within the walls of large hyphal fragments or hyphal aggregates (mycelia).

The lack of transstadial transmission of Pythium DNA or viable propagules reported herein and by Jarvis et al. (15) is not unexpected. Insects undergo profound structural and physiological changes (histolysis/histogenesis) during metamorphosis that present a considerable barrier to persistence of ingested materials. The insect foregut and hindgut linings (intima) are shed during each molt and, during the pupal stage of holometabolous insects, the midgut is completely reformed around the larval gut, which is then assimilated for reuse. Following emergence from the pupal cuticle, waste from this and other processes is voided as a fecal fluid called the meconium (2). Many studies have reported a lack of transstadial transmission of plant-pathogenic viruses, bacteria, and fungi by insects $(3,19,22,24)$. El-Hamalawi (5) found that fungus gnat larvae that fed on either Verticillium dahliae, Fusarium acuminatum, or $T$. basicola developed into internally infested pupae. However, as in our study, emerging adults were void of fungal propagules. In one case where transstadial retention of a plant-pathogenic bacterium, Serratia marcescens Bizio, was observed, only 9 of 82 squash bugs that fed on Serratia as fifth-instar nymphs transmitted the bacterium to plants as adults (31). The process of metamorphosis also differs significantly between hemimetabolous insects such as squash bugs and holometabolous insects such as flies, and distinctive stages in their life cycles could explain the unique transstadial transmission potential of certain insect groups.

The findings of this study enhance our understanding of the association between fungus gnats and Pythium spp. in greenhouse floriculture. The molecular assay that we developed for speciesspecific detection and quantification of $P$. aphanidermatum will likely be useful to plant pathologists and entomologists for a variety of future studies. Although we have demonstrated that fungus gnats are unlikely vectors of Pythium spp., relaxing management strategies for fungus gnats is not currently warranted. Fungus gnats should still be considered pests in most cases because they are capable of directly wounding plants and transmitting several plant-pathogenic conidial fungi $(10,12,16)$. Future disease epidemiology studies with fungus gnats should focus on pathogen-vector-host specificity and the likelihood of transmission in various ecological settings.

\section{ACKNOWLEDGMENTS}

We thank E. Nelson of Cornell University for providing strains of $P$. aphanidermatum and P. ultimum and M. Ramos and K. C. Bennett for technical support. This research was funded, in part, through Specific Cooperative Agreements between the United States Department of Agriculture-Agricultural Research Service (USDA-ARS) Plant Protection Research Unit and the Cornell University Department of Entomology, Ithaca, NY (Specific Cooperative Agreements 58-1907-5-555 and 58-1907-4-447) funded by the USDA-ARS, as part of the Floriculture and Nursery Research Initiative. Additional funding came from an NSF Graduate Research Fellowship and a Grace H. Griswold Endowment Grant to S. E. Braun.

\section{LITERATURE CITED}

1. Braun, S. E., Sanderson, J. P., Nelson, E. B., Daughtrey, M. L., and Wraight, S. P. 2009. Fungus gnat feeding and mechanical wounding inhibit Pythium aphanidermatum infection of geranium seedlings. Phytopathology 99:1421-1428.

2. Chapman, R. F. 1998. The Insects Structure and Function. 4th ed. Cambridge University Press, Cambridge.

3. Clarke, R. G., and Wilde, G. E. 1970. Association of the green stink bug and the yeast-spot disease organism of soybeans. 1. Length of retention, effect of molting, isolation from feces and saliva. J. Econ. Entomol. 61:200-204.

4. Delinger, D. L., and Žd'árek, J. 1994. Metamorphosis behavior of flies. Annu. Rev. Entomol. 39:243-266.

5. El-Hamalawi, Z. A. 2008. Acquisition, retention and dispersal of soilborne plant pathogenic fungi by fungus gnats and moth flies. Ann. Appl. Biol. 153:195-203.

6. El-Hamalawi, Z. A., and Stanghellini, M. E. 2005. Disease development on Lisianthus following aerial transmission of Fusarium avenaceum by adult shore flies, fungus gnats, and moth flies. Plant Dis. 89:619-623.

7. Elmer, W. H. 2008. Preventing spread of Fusarium wilt of Hiemalis begonias in the greenhouse. Crop Prot. 27:1078-1083.

8. Favrin, R. J., Rahe, J. E., and Mauza, B. 1988. Pythium spp. associated with crown rot of cucumbers in British Columbia greenhouses. Plant Dis. 72:683-687.

9. Gardiner, R. B., Jarvis, W. R., and Shipp, J. L. 1990. Ingestion of Pythium spp. by larvae of the fungus gnat Bradysia impatiens (Diptera: Sciaridae). Ann. Appl. Biol. 116:205-212. 
10. Gillespie, D. R., and Menzies, J. G. 1993. Fungus gnats vector Fusarium oxysporum f. sp. radicis-lycopersici. Ann. Appl. Biol. 123:539-544.

11. Harris, M. A. 1995. Dissemination of the phytopathogen Thielaviopsis basicola by the fungus gnat Bradysia coprophila and biological control of these pests by Fusarium proliferatum and steinernematid nematodes. Doctoral dissertation, University of Georgia, Athens.

12. Harris, M. A., Gardner, W. A., and Oetting, R. D. 1996. A review of the scientific literature on fungus gnats (Diptera: Sciaridae) in the genus Bradysia. J. Entomol. Sci. 31:252-271.

13. Hong, C. X., and Moorman, G. W. 2005. Plant pathogens in irrigation water: challenges and opportunities. Crit. Rev. Plant Sci. 24:189-208.

14. Hyder, N., Coffey, M. D., and Stanghellini, M. E. 2009. Viability of oomycete propagules following ingestion and excretion by fungus gnats, shore flies, and snails. Plant Dis. 93:720-726.

15. Jarvis, W. R., Shipp, J. L., and Gardiner, R. B. 1993. Transmission of Pythium aphanidermatum to greenhouse cucumber by the fungus gnat Bradysia impatiens (Diptera: Sciaridae). Ann. Appl. Biol. 122:23-29.

16. Kalb, D. W., and Millar, R. L. 1986. Dispersal of Verticillium albo-atrum by the fungus gnat (Bradysia impatiens). Plant Dis. 70:752-753.

17. Kennedy, M. K. 1974. Survival and development of Bradysia impatiens (Diptera: Sciaridae) on fungal and non-fungal food sources. Ann. Entomol. Soc. Am. 67:745-749.

18. Lévesque, C. A., and De Cock, W. A. M. 2004. Molecular phylogeny and taxonomy of the genus Pythium. Mycol. Res. 108:1363-1383.

19. Ling, K. C. 1966. Nonpersistence of the tungro virus of rice in its leafhopper vector, Nephotettix impecticeps. Phytopathology 56:12521256.

20. Middleton, J. T. 1943. The taxonomy, host range and geographic distribution of the genus Pythium. Mem. Torrey Bot. Club 20:1-171.
21. Moorman, G. W., Kang, S., and Geiser, D. M. 2002. Identification and characterization of Pythium species associated with greenhouse floral crops in Pennsylvania. Plant Dis. 86:1227-1231.

22. Nault, L. R., Styer, W. E., Knoke, J. K., and Pitre, H. N. 1973. Semipersistent transmission of leafhopper-borne maize chlorotic dwarf virus. J. Econ. Entomol. 66:1271-1273.

23. Powell, C. C. 1995. Fungus gnats and Pythium root rot. Cleary's Hort Talk 2:1-2.

24. Purcell, A. H., and Finlay, A. 1979. Evidence for noncirculative transmission of Pierce's disease bacterium by sharpshooter leafhoppers. Phytopathology 69:393-395.

25. Ruben, D. M., Frank, Z. R., and Chet, I. 1980. Factors affecting behavior and developmental synchrony of germinating oospores of Pythium aphanidermatum. Phytopathology 70:54-59.

26. SAS Institute. 2002. JMP. Statistics and Graphics Guide: Version 4. SAS Institute Inc., Cary, NC.

27. Steffan, W. A. 1966. A generic revision of the family Sciaridae (Diptera) of America north of Mexico. Univ. Calif. Publ. Entomol. 44:1-77.

28. Van der Plaats-Niterink, A. J. 1981. Monograph of the genus Pythium. Stud. Mycol. 21:1-239.

29. van West, P., Appiah, A. A., and Gow, N. A. R. 2003. Advances in research on oomycete root pathogens. Physiol. Mol. Plant P. 62:99-113.

30. Wang, P. H., Wang, Y. T., and White, J. G. 2003. Species-specific PCR primers for Pythium developed from ribosomal ITS1 region. Lett. Appl. Microbiol. 37:127-132.

31. Wayadande, A., Bruton, B., Fletcher, J., Pair, S., and Mitchell, F. 2005. Retention of cucurbit yellow vine disease bacterium Serratia marcescens through transstadial molt of vector Anasa tristis (Hemiptera: Coreidae). Ann. Entomol. Soc. Am. 98:770-774. 